\title{
THE INFLUENCE \\ OF CALCIUM NITRATE FERTILIZATION ON THE NUMBER OF MICROORGANISMS IN SOILS UNDER TEA PLANT IN THE SUBTROPICAL ZONE OF RUSSIA
}

\author{
Malyukova L. S., Rogozhina Ye. V. \\ Federal Research Centre \\ the Subtropical Scientific Centre of the Russian Academy of Sciences, \\ Sochi,Russia,e-mail: MalukovaLS@mail.ru
}

Long-term use of the main group of mineral fertilizers (NPK) in agroecosystems has a significant impact on soils' properties, their nutritional regime, as well as on the availability of plant elements. In this aspect, it is of particular interest to study the effects of calcium which is not considered as a priority, but is a basic structural and signaling element in nutrition system of a tea plant that relates to acidophilic plants. In the field experiment, calcium nitrate applied on roots (as an alternative to ammonium nitrate) effected on the number of the main taxonomic groups of soil microbiocenosis: saprotrophic bacteria, actinomycetes and micromycetes, quantitative accounting of which was carried out by surface seeding from 10-fold dilutions on dense selective nutrient media. It was found that calcium nitrate led to an increase in the number of saprotrophic bacteria and caused changes in their morphological characteristics. As for mycelial groups of microorganisms, there was recorded a decrease in the number of micromycetes belonging to acidophilic microorganisms, as well as a significantly more pronounced sporulation of actinomycetes under the influence of fertilizers with calcium.

Key words: tea plant, microbiocenosis, calcium, biogenic elements, ecological conditions, mineral fertilizers.

УДК 001.8:631.41+631.48

doi: $10.31360 / 2225-3068-2020-75-149-158$

\section{ВЛИЯНИЕ ЦИНКОСОДЕРЖАЩИХ УДОБРЕНИЙ НА ИЗМЕНЕНИЕ КИСЛОТНОСТИ В РИЗОСФЕРЕ ЧАЯ (CAMELLIA SINENSIS L.) СОРТА 'КОЛХИДА' В УСЛОВИЯХ СУБТРОПИЧЕСКОЙ ЗОНЫ РОССИИ}

Рогожина E. B.

\author{
Федеральное государственное бюджетное учреждение науки \\ «Федеральный исследовательский иентр «Субтропический научный иентр \\ Российской академии наук», \\ 2. Сочu, Россия, e-mail: RogojinaEW@yandex.ru
}

\begin{abstract}
В агроэкоценозе чайной плантации в условиях Сочинского Черноморского побережья проведено сравнительное изучение кислотности бурых лесных кислых почв в ризосфере растений чая и внекорневой зоне на фоне N240P70K90 (контроль) и при внесении сульфата цинка в дозе 4,3 кг д.в./га (на фоне N240P70К90).
\end{abstract}


Отмечена тенденция подкисления относительно контроля в ризосфере (в среднем на 0,25 ед. $\mathrm{pH}$ ) и во внекорневой почве (в среднем на 0,1 ед. $\mathrm{pH}$ ) в результате внесения микроудобрений с цинком. Отмечено увеличение кислотности (в среднем на 0,6 единиц) почв двух локусов обоих вариантов в постстрессовый период (после засухи). Показано, что в период активного влияния удобрений (май) изменение кислотности в ризосфере обоих вариантов имело нестабильный характер ( $\pm 0,1$ единица), а в период физиологического покоя (февраль) или депрессии (август) - кислотность незначительно снижалась (на 0,1 ед. $\mathrm{pH}$ ). Отмечено повышение кислотности в ризосфере под влиянием сульфата цинка осенью (октябрь), что, возможно, связано с влиянием микроудобрений на функциональную активность растительно-микробной системы.

Ключевые слова: бурые лесные кислые почвы, чайная плантация, цинкосодержащие удобрения, кислотность ризосферы и внекорневой почвы.

Кислотность почвенного раствора важный экологический, а в зоне ризосферы (до 3 мм от корня), ещё и физиологический показатель, отражающий интенсивность выделения корнями растения подкисляющих экссудатов (неорганические ионы $\mathrm{HCO}_{3}^{-}, \mathrm{H}^{+} ; \mathrm{CO}_{2}$, низкомолекулярные органические и жирные кислоты) [20]. Микроорганизмы, ассоциированные с растением, также способны влиять на $\mathrm{pH}$ среды, изменяя его как в кислую (в результате «дыхания»), так и в нейтральную сторону в результате выделения метаболитов, что является механизмом устойчивости к существованию в условиях высокой концентрации протонов $\mathrm{H}^{+}$ и $\mathrm{Al}^{3+}[16-18]$. Все эти адаптационные процессы характерны для агроэкосистемы чая (Camellia sinensis (L.) Kuntze) [3, 4, 12, 13, 22, 23]. Чай возделывается на кислых почвах, с применением физиологически кислых минеральных удобрений, что приводит к снижению рН и повышению содержания алюминия в почве и растении [8]. С целью повышения урожайности культуры чая и адаптации к стресс-факторам (в первую очередь летнему гидротермическому стрессу, характерному для зоны с влажно-субтропическим климатом) исследуют влияние микроудобрений, содержащих важные биогенные элементы, в том числе цинк, входящий в состав целого ряда ферментативных систем живых клеток [9]. При длительной эксплуатации чайной плантации почвы обедняются подвижным цинком и его внесение становится необходимым [6, 7]. Одновременно цинк является высокотоксичным тяжёлым металлом (TM), оказывающим воздействие как на растение, так и на активность почвенных микрооганизмов $[10,19,25]$. Ранее было установлено влияние цинкосодержащих удобрений на численность основных групп микробоценоза ризосферы чая, приводящее к снижению численности 
прокариот (сапротрофных бактерий, актиномицетов), обладающих низкой резистентностью к фактору кислотности [11]. Таким образом, изменение кислотности в ризосфере чая является отражением целого комплекса адаптационных процессов в системе чайное растение-почва-микроорганизмы: экссудации корнями и состава экссудатов, деятельности микроорганизмов; влияния удобрений, их взаимодействия, влияния климатических факторов. В связи с этим целью исследований являлось изучение кислотности почвы в ризосфере чайного растения и во внекорневой зоне, а также её изменения под влиянием цинкосодержащих микроудобрений на протяжение вегетационного периода.

Объекты и методы исследования. Исследования проводили на базе полевого опыта с мезо- и микроудобрениями. Опыт заложен в 2003 г. на чайной плантации сорта 'Колхида' (Camellia sinensis (L.) Kuntze) 1983 г. посадки (ЗАО «Дагомысчай», пос. Уч-Дере, г. Сочи, Лазаревский район, 0,3 га, 43,69 N, 39,64 E). Изучали агрогенно-измененные бурые лесные кислые почвы [5]. Отбирали почвенные образцы в течение 2 вегетационных периодов 2014-2015 гг. Изучали вариант с внесением сульфата цинка в поверхностный слой почвы в дозе 4,3 кг д.в./га на фоне макроудобрений N240P70К90 кг д.в./га. Макро- и микроудобрения вносили в апреле, в июне осуществляли подкормку азотом. Контролем служил вариант без внесения цинка (N240P70K90). Фоновое содержание подвижных форм цинка в почве (3,2 мг/кг) [6]. Смешанные образцы корней чая с прилегающей к ней почвой и почвы свободной от корней были отобраны с соблюдением условий стерильности с глубины 10-20 см. Этот слой (горизонт $A_{1}$ ) был выбран как наиболее подверженный агрогенному воздействию (внесение удобрения) и при этом в меньшей степени содержащий растительные остатки (по сравнению с поверхностным горизонтом $\mathrm{A}_{0}$ ). Для исследований, согласно общепринятым методикам по изучению прикорневой зоны растений $[14,15]$, использовался слой почвы 1 мм, непосредственно примыкающий к корням (корневая зона ризосферы) и почва свободная от корней (расстояние от корня более 3-5 мм).

Кислотность почвенного раствора $\mathrm{pH}_{\text {ксl }}$ была определена потенциометрически в суспензии при соотношении почва: раствор 1н $\mathrm{KCl}$ равном $1: 2,5$ (ионометр рН-121) [1]. Полевая влажность определена весовым методом.

Результаты и их обсуждение. Исследования проводили во влажносубтропической зоне Черноморского побережья Краснодарского края, где средняя многолетняя температура варьирует в пределах $12,8-16,5^{\circ} \mathrm{C}$, годовое количество осадков 1 313-2 098 мм. В августе отмечается температурный максимум и дефицит осадков. Динамика среднесуточной 
температуры и количества осадков по месяцам за два года исследования (по данным метеостанции г. Сочи http://www.pogodaiklimat.ru/ history/37099.htm) представлены на рисунке 1.

2015 г. в сравнении с 2014 г. характеризовался более ранним началом летнего гидротермического стресса (июль), что отразилось на влажности почвы уже в августе (в среднем на 10,5 \% ниже, чем в августе 2014 г.) (табл. 1).

Таблица 1

Влажность почвенных образцов (\%) различных локусов по вариантам опыта

в годовой динамике, слой 10-20 cм

\begin{tabular}{|c|c|c|c|c|c|c|}
\hline \multirow{2}{*}{ Год } & \multirow{2}{*}{$\begin{array}{c}\text { Почвенные } \\
\text { локусы }\end{array}$} & \multirow{2}{*}{ Вариант } & \multicolumn{4}{|c|}{ Месяц } \\
\hline & & & февраль & май & август & октябрь \\
\hline \multirow{2}{*}{2014} & \multirow{2}{*}{ ризосфера } & контроль & 34 & 35 & 35 & 36 \\
\hline & & цинк & 37 & 37 & 47 & 31 \\
\hline \multirow{4}{*}{2015} & \multirow{2}{*}{ ризосфера } & контроль & 38 & 36 & 29 & 40 \\
\hline & & цинк & 39 & 37 & 32 & 37 \\
\hline & \multirow{2}{*}{$\begin{array}{l}\text { внекорневая } \\
\text { зона }\end{array}$} & контроль & 31 & 38 & 28 & 33 \\
\hline & & цинк & 42 & 36 & 31 & 32 \\
\hline
\end{tabular}

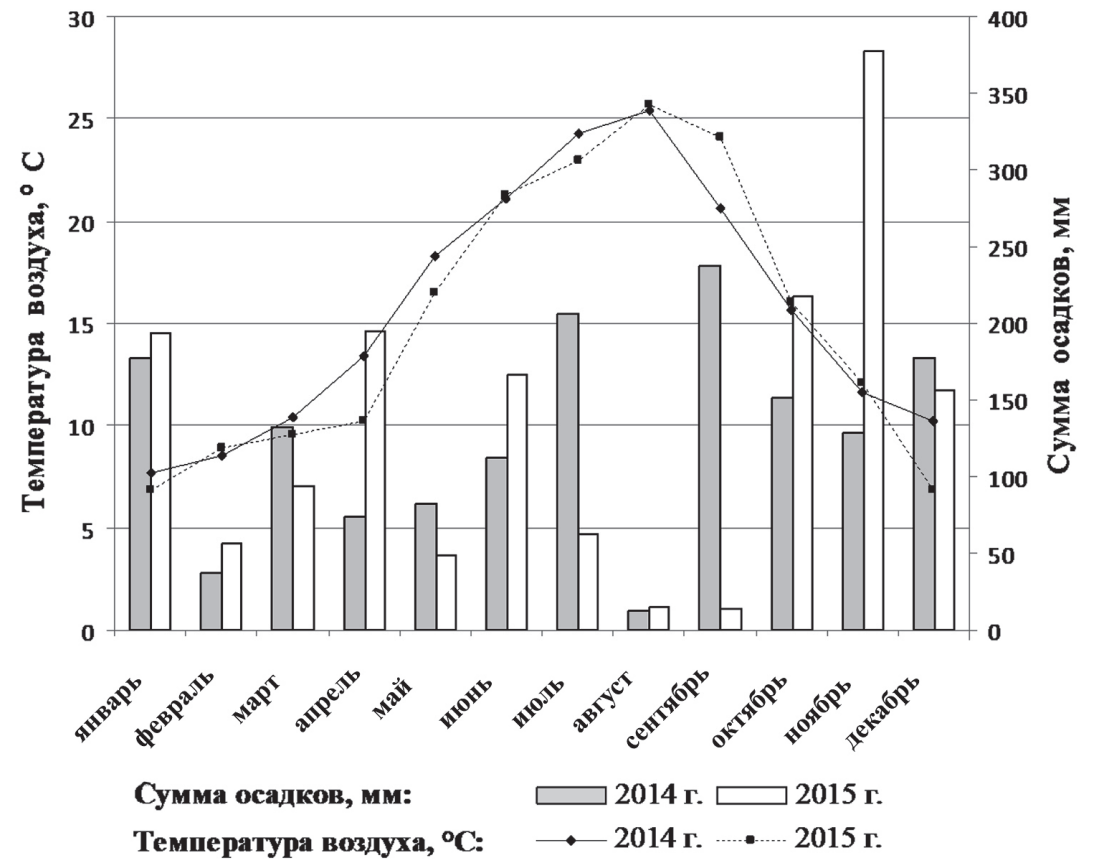

Рис. 1. Среднемесячные дневные температуры воздуха и суммы осадков в г. Сочи 
Глава 6 Агрохимия и почвоведение

Можно отметить, что в обоих вариантах в целом наблюдалось увеличение влажности в ризосфере, в сравнение с почвой свободной от корней, что отмечали и другие авторы [27]. Это связывают с накоплением в ризосфере высокомолекулярных полисахаридов, увеличивающих способность почвы удерживать влагу [20]. Полисахариды выделяются как корнем растения, образуя тонкий слой на его поверхности (муцигель), так и микроорганизмами, как один из механизмов, обеспечивающих устойчивость к кислым почвам и токсичности ионов $\mathrm{Al}^{3+}$ и $\mathrm{H}^{+}$.

Изучение кислотности почвы сравниваемых вариантов опыта в ризосфере и во внекорневой зоне показало подкисление в течение всего вегетационного периода 2014 г. в варианте с цинком относительно контроля (снижение $\mathrm{pH}$ на $0,05-0,14$ единиц в почве; на $0,10-0,41$ единиц в ризосфере), а в 2015 г. - только в октябре (снижение на 0,10 и 0,26 единиц в почве и ризосфере, соответственно) (рис. 2). Самые низкие показатели рН (т. е. самая высокая кислотность) были отмечены в почве обоих вариантов в октябре 2015 г. В сравнении с октябрем 2014 г они были в варианте с цинком $\mathrm{pH}$ ниже на 0,63 и 0,56 единиц, а в контроле - на 0,64 и 0,61 единиц (в почве и ризосфере, соответственно) (рис. 2). Это может быть связано с последействием 3-месячной (июль - сентябрь) засухи в 2015 г., которая, по-видимому, способствовала увеличению содержания $\mathrm{H}^{+}$в почвенных растворах. Увеличение кислотности почв на фоне снижения влажности, было отмечено и для других типов почв [2].

В целом за период исследования диапазоны варьирования $\mathrm{pH}_{\mathrm{KCl}}$ по вариантам опыта составили: контроль - от 2,96 до 3,64 единиц в почве и от 3,10 до 3,71 единиц в ризосфере; вариант с цинком - от 2,87 до 3,55 единиц в почве и от 2,84 до 3,55 единиц в ризосфере, что также демонстрирует тенденцию подкисления почв в результате внесения цинксодержащих микроудобрений.

Результаты изменения $\mathrm{pH}_{\mathrm{KCl}}$ в ризосфере по сравнению с внекорневой почвой, полученные в течение вегетационных периодов 2014 и 2015 гг. показали, что в варианте с сульфатом цинка подкисление в течение 2 лет было отмечено только в октябре (рис. 3). Если учесть, что подкисление в ризосфере определяется интенсивностью выделения корнями подкисляющих экссудатов и микробного дыхания, то можно предположить, что цинкосодержащие удобрения стимулируют эти процессы в осенний период. Различия по годам (в 2015 г. подкисление на 0,17 единиц меньше) обусловлены снижением активности растений и микроорганизмов в постстрессовый период. В ризосфере контрольного варианта наблюдалось в основном снижение кислотности (исключая май 2014 г.), что согласно литературным данным, является характерной особенностью чайного растения и связано с адаптационным метаболизмом микроорганизмов [3, 21, 24]. 


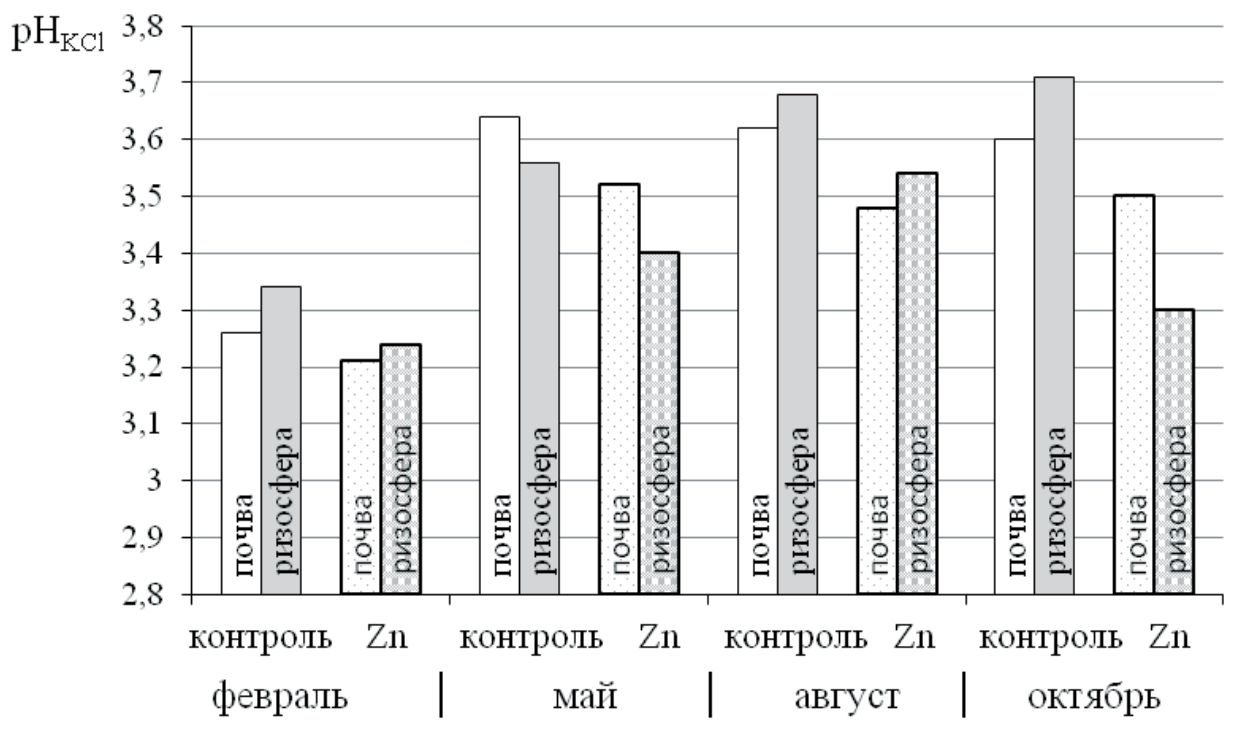

2014 г.

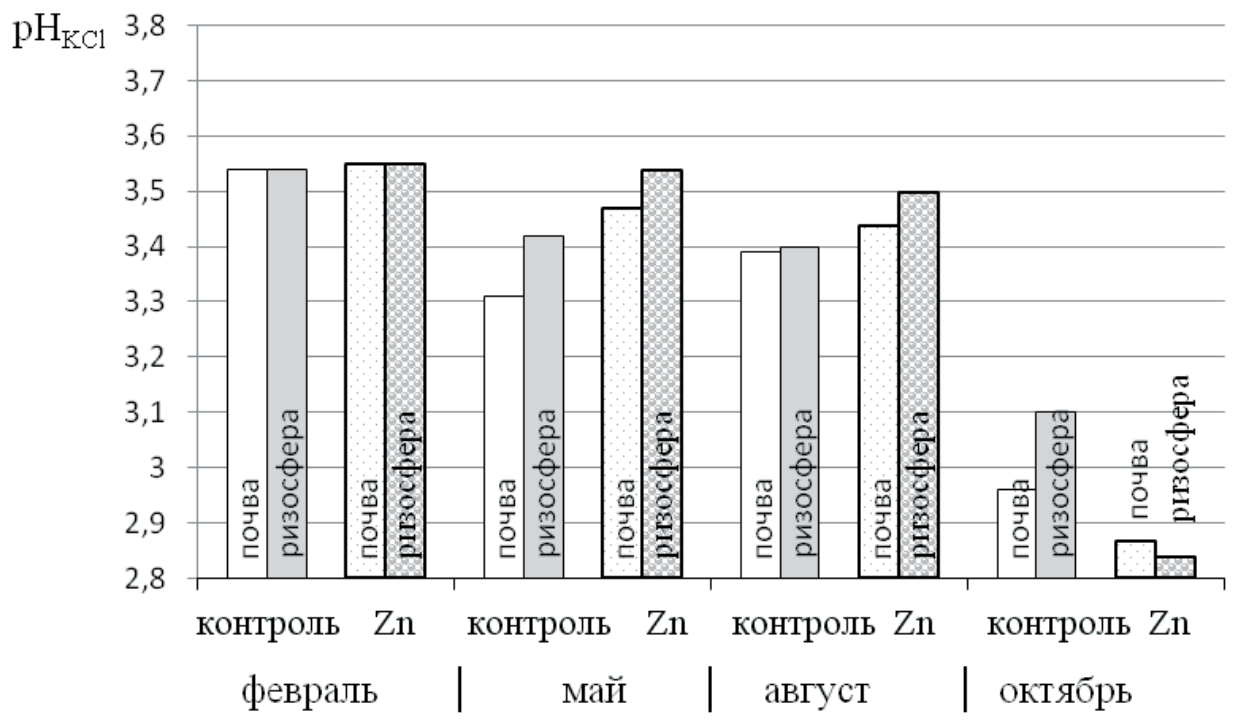

2015 г.

Рис. 2. Кислотность почвенного раствора в сезонной динамике по вариантам опыта

Противоположные тенденции изменения кислотности в ризосфере чая относительно внекорневой почвы обоих вариантов в мае 2014 г. (подкисление) и мае 2015 г. (снижение кислотности), по-видимому, обусловлены 
нестабильным физиологическим состоянием растения и микроорганизмов через месяц после внесения удобрений (в апреле). Состояние физиологической депрессии чайного растения (февраль, август) характеризовалось снижением кислотности в ризосфере обоих вариантов.

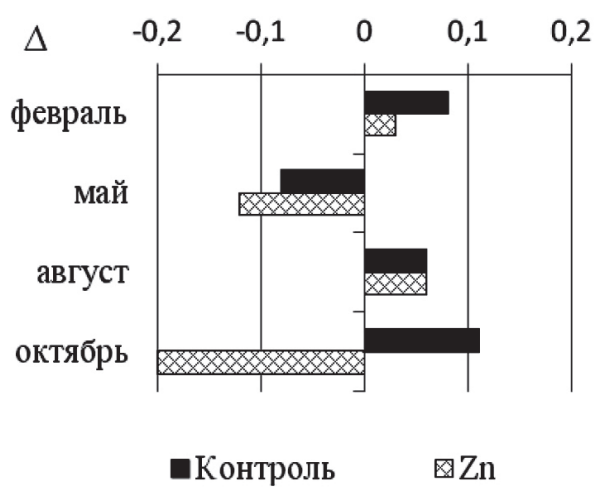

2014 г.

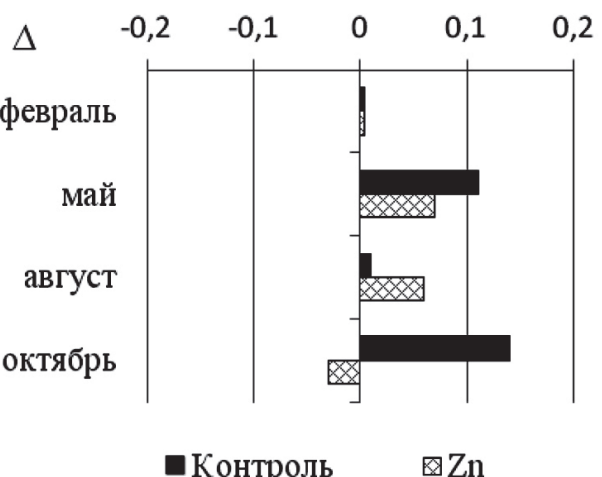

2015 г.

Примечание: $\Delta-$ разность $\mathrm{pH}_{\text {ризосферь }}-\mathrm{pH}_{\text {почвы }}$

Рис. 3. Изменение кислотности в ризосфере чайного растения под влиянием цинкосодержащих удобрений на фоне N240P70К90 в сравнении с контролем

Заключение. Таким образом, было изучено влияние цинкосодержащих микроудобрений в дозе 4,3 кг д.в./га на фоне макроудобрений (N240P70K90) на кислотность как в почве, так и в ризосфере чая в течение всего вегетационного периода, в т. ч. под влиянием стресс-факторов (засуха). Была выявлена тенденция подкисления внекорневой почвы (от 0,05 до 0,14 единиц) и ризосферы (от 0,1 до 0,41 единицы) в результате внесения цинкосодержащих микроудобрений. В ризосфере обоих вариантов было определено нестабильное состояние кислотности (как подкисление, так и подщелачивание) через месяц после внесения удобрений (май) и снижение кислотности на фоне физиологической депрессии растения (февраль, август). В течение 2 лет было отмечено повышение кислотности в ризосфере под влиянием сульфата цинка осенью (октябрь), что, возможно, связано с влиянием микроудобрений на функциональную активность растительно-микробной системы в этот период. Самые низкие показатели рН за весь период исследования были отмечены в почве и ризосфере обоих вариантов в октябре 2015 г., после продолжительной засухи, что связано с влиянием влажности почвы на состав почвенных растворов. 


\section{Библиографический список}

1. Агрохимические методы исследования почв / отв. ред. А.В. Соколов. - М.: Наука, 1975. $-656 \mathrm{c}$.

2. Анисимов В.С., Санжаров А.И., Корнеев Ю.Н., Анисимова Л.Н., Морозова А.И., Фригидов Р.А., Кочетков И.В. Влияние влажности почвы на химический состав и кислотность квазиравновесных почвенных растворов // Биогеохимия - научная основа устойчивого развития и сохранения здоровья человека», Тула, 13-15 июня, 2019 г.: сб. трудов конференции. - Тула: ТГПУ им. Л.Н. Толстого. 2019. - С. 199-203. - ISBN 978-5-6042450-0-2.

3. Дараселия Н.А. Биологическая активность основных почв Западной Грузии. - Тбилиси: «Мецниереба», 1979. - 302 с.

4. Дараселия Н.А. Некоторые данные микробиологической характеристики почв Западной Грузии в условиях чайных плантаций // Бюллетень ВНИИ чая и субтропических культур. - Махарадзе, Анасеули. 1952. - № 2. - С. 141-147.

5. Классификация и диагностика почв СССР. - М.: Колос, 1977. - 224 с.

6. Малюкова Л.С. Состояние микроэлементов (Mn, $\mathrm{Cu}, \mathrm{Zn})$ в бурых лесных почвах чайных плантаций Черноморского побережья Краснодарского края». автореф. дис. ... канд. биол. наук. - М., 1998 - 30 с.

7. Малюкова Л.С., Малинина М.С. Особенности поведения металлов (Mn, Zn, Cu) в бурой лесной кислой почве под чайной плантацией в условиях влажных субтропиков России // Агрохимия. - 2001. - № 3. - С. 62-68. - ISSN 0002-1881.

8. Малюкова Л.С., Козлова Н.В., Притула 3.В. Система удобрения плантаций чая в субтропиках России. - Сочи: ВНИИЦиСК, 2010. - 45 с.

9. Малюкова Л.С., Козлова Н.В., Великий А.В. Влияние мезо- и микроудобрений на урожай чайного листа и плодородие бурых лесных кислых почв чайных плантаций почв чайных плантаций Черноморского побережья России // Проблемы агрохимии и экологии. - 2012. - № 1. - С. 18-21. - ISSN 2072-0386.

10. Мосина Л. В. Основы экотоксикологии: учебное пособие. - М.: Изд-во РГАУMCXA, 2013. - 100 c. - ISBN 978-5-9675-0808-0.

11. Рогожина Е.В. Влияние цинкосодержащих удобрений на микробный комплекс ризосферы чайного растения (Camellia sinensis L.) в условиях субтропической зоны России // Субтропическое и декоративное садоводство. - 2016. - Вып. 57. - С. 179185. - ISSN 2225-3068.

12. Рогожина Е. В. Сравнительный анализ микробного комплекса почвы и ризосферы чайного растения (Camellia sinensis L.) на бурых лесных кислых окультуренных почвах субтропической зоны России // Субтропическое и декоративное садоводство. 2014a. - Вып. 51. - С. 290-296. - ISSN 2225-3068.

13. Рогожина Е.В. Особенности комплекса ризосферных микроорганизмов чайного растения (Camellia sinensis) в условиях субтропической зоны России // Садоводство и виноградарство. - 2014б. - № 4. - С. 45-48. - ISSN 0235-2591.

14. Шапошников А.И., Пухальский Я.В., Кравченко Л.В., Белимов А.А. Роль корневой экссудации в трофических взаимодействиях растений с ризосферными микроорганизмами / под ред.: И.А. Тихонович. - СПб.: Информ-Навигатор, 2016. - 104 с.

15. Широких А.А., Мерзаева О.В., Широких И.Г. Методические подходы к изучению микроорганизмов прикорневой зоны растений (обзор) // Сельскохозяйственная биология. - 2007. - № 1. - С. 43-55. - ISSN 0131-6397.

16. Широких И.Г., Широких А.А., Родина Н.А., Полянская Л.М., Бурканова О.А. Влияние кислотности почвы и токсичности алюминия на структуру микробной биомассы в ризосфере ячменя // Почвоведение. - 2004. - № 8. - С. 961-966. - ISSN 0032-180X. 
17. Широких А.А. Изучение микробного потенциала фитосферы растений для использования в сельскохозяйственной биотехнологии: автореф. дис. ... д-ра биол. наук. - Киров: ЗНИИСХ Северо-Востока, 2007. - 48 с.

18. Gadd G. M. Heavy metal accumulation by bacteria and other microorganisms. - Experientia, 1990. - 46. - P. 834-840.

19. Jadwiga Wyszkowska, AgataBorowik, Miros³aw Kucharski, Jan Kucharski. Effect of cadmium, copperend zinc on plants, soilmicroorganisms and soil enzymes // Chair of MicrobiologyUniversity of Warmia and Mazury in Olsztyn // 20. J. Elem. - P. 769796. - doi: 10.5601/jelem.2013.18.4.455

20. Marschner H. Mineral Nutrition of Higher Plants. - London: Academic Press, 1986. - 889 p. 21. Morita A., Fujii Y., Yokota H. Effect of aluminium on exudation of organic acid anions in tea plants // Plant Nutrition-Food Security and Sustainability of Agro-ecosystems through Basic and Applied Research. - Kluwer: Dordrecht, 2001. - P. 508-509.

22. Morita O., Yanagisawa S., Takatsu S., Maeda S., Hiradate Mechanism for the Detoxification of Aluminum in Roots of Tea Plant (Camellia sinensis (L.) Kuntze) // Phytochemstry. - 2008. - Vol. 69. - № 1. - P. 147-153. - doi: 10.1016/j.phytochem.2007.06.007

23. Pandey A., Palni L.M.S. The Rhizosphere Effect in trees of the Indian Central Himalaya with special reference to altitude // Applied Ecology end Environmental Research. - 2007. - Vol. 5. - № 1. - P. 93-102. - ISSN 1589-1623.

24. Pandey A. Palni L.M.S. The rhizosphere effect of tea on soil microbes in a Himalayan monsoonal location // Biol Fert Soils [04.06.17]. - 1996. - Vol. 21. - № 3. - P. 131-137. ISSN 0178-2762.

25. Venkatesan S., Hemalatha K.V., Jayaganesh S. Zinc toxicity and its infuence nutrient uptake in tea // American Journal of Plant Physiology. - 2006. - № 1(2). - P. 185-192. - ISSN 1557-4539. 26. Working Group WRB. World Reference Base for Soil Resources 2014. International soil classification system for naming soils and creating legends for soil maps. World Soil Resources Reports. - Rome: FAO, 2014. - Vol. 106. - 181 p. - ISBN 978-92-5-108369-7. 27. Young I. M. Variation in moisture contents between bulk soil and rhizosheath of wheat (Triticum aestivum L. cv. wembley) // New Phytologist. - 1995. - Vol. 130. - P. 135-139. - ISSN 0028-646X.

\title{
THE EFFECT OF ZINC-CONTAINING FERTILIZERS ON CHANGING ACIDITY IN TEA PLANT RHIZOSPHERE (CAMELLIA SINENSIS L.) CV. 'KOLKHIDA' IN THE SUBTROPICAL ZONE OF RUSSIA
}

\author{
Rogozhina Ye. V. \\ Federal Research Centre the Subtropical Scientific Centre \\ of the Russian Academy of Sciences, \\ Sochi,Russia,e-mail: RogojinaEW@yandex.ru
}

The paper deals with the comparative study of acidity in brown forest acid soils in tea plant rhizosphere and foliar sphere on the background N240P70K90 (control), and during zinc sulphate application ( $4.3 \mathrm{~kg}$ of AD/ha) (on the background N240P70K90) in agroecocenosis of tea plantation on Sochi Black Sea coast. There was noted a tendency of acidification relative to the control in the rhizosphere (on average by $0.25 \mathrm{pH}$ units) and in foliar soil (on average by $0.1 \mathrm{pH}$ units) as a result 
Субтропическое и декоративное садоводство (75)

of application of microfertilizers with zinc. There was an increase in soil acidity (on average by 0.6 units) of two locuses for both variants in the post-stress period (after a drought). It is shown that during the period of active fertilizers' effect (May), the change in acidity was unstable in the rhizosphere of both variants ( \pm 0.1 units), and during the period of physiological dormancy (February) or depression (August), the acidity decreased slightly (by $0.1 \mathrm{pH}$ units). An increase in acidity in the rhizosphere under the influence of zinc sulfate was noted in autumn (October), which may be due to the effect of microfertilizers on the functional activity of plant-microbial system.

Key words: brown acid forest soils, tea plantation, zinc-containing fertilizers, acidity of rhizosphere and leaf soil. 